\title{
Titanium dioxide induces apoptotic cell death through reactive oxygen species-mediated Fas upregulation and Bax activation
}

This article was published in the following Dove Press journal:

International Journal of Nanomedicine

3 March 2012

Number of times this article has been viewed

\author{
Ki-Chun Yoo' \\ Chang-Hwan Yoon' \\ Dongwook Kwon ${ }^{2}$ \\ Kyung-Hwan Hyun' \\ Soo Jung Woo' \\ Rae-Kwon Kim' \\ Eun-Jung Lim' \\ Yongjoon Suh' \\ Min-Jung Kim' \\ Tae Hyun Yoon ${ }^{2}$ \\ Su-Jae Lee' \\ 'Laboratory of Molecular \\ Biochemistry, ${ }^{2}$ Laboratory \\ of Nanoscale Characterization and \\ Environmental Chemistry, Department \\ of Chemistry, Hanyang University, \\ Seoul, Republic of Korea
}

Co-correspondence: Su-Jae Lee Laboratory of Molecular Biochemistry,

Department of Chemistry, Hanyang

University, 17 Haengdang-Dong,

Seongdong-Ku, Seoul I33-79I, Korea

Tel +82 222202557

Fax +822 22990762

Email sj0420@hanyang.ac.kr

or

Tae Hyun Yoon

Laboratory of Nanoscale

Characterization and Environment

Chemistry, Department of Chemistry,

Hanyang University, Seoul I33-79I, Korea

Tel +82 222204593

Email thyoon@gmail.com
Background: Titanium dioxide $\left(\mathrm{TiO}_{2}\right)$ has been widely used in many areas, including biomedicine, cosmetics, and environmental engineering. Recently, it has become evident that some $\mathrm{TiO}_{2}$ particles have a considerable cytotoxic effect in normal human cells. However, the molecular basis for the cytotoxicity of $\mathrm{TiO}_{2}$ has yet to be defined.

Methods and results: In this study, we demonstrated that combined treatment with $\mathrm{TiO}_{2}$ nanoparticles sized less than $100 \mathrm{~nm}$ and ultraviolet A irradiation induces apoptotic cell death through reactive oxygen species-dependent upregulation of Fas and conformational activation of Bax in normal human cells. Treatment with $\mathrm{P}_{2} 5 \mathrm{TiO}_{2}$ nanoparticles with a hydrodynamic size distribution centered around $70 \mathrm{~nm}\left(\mathrm{TiO}_{2}{ }^{\mathrm{P} 25-70}\right)$ together with ultraviolet $\mathrm{A}$ irradiation-induced caspase-dependent apoptotic cell death, accompanied by transcriptional upregulation of the death receptor, Fas, and conformational activation of Bax. In line with these results, knockdown of either Fas or Bax with specific siRNA significantly inhibited $\mathrm{TiO}_{2}$-induced apoptotic cell death. Moreover, inhibition of reactive oxygen species with an antioxidant, $\mathrm{N}$-acetyl-L-cysteine, clearly suppressed upregulation of Fas, conformational activation of Bax, and subsequent apoptotic cell death in response to combination treatment using $\mathrm{TiO}_{2}{ }^{\mathrm{P} 25-70}$ and ultraviolet $\mathrm{A}$ irradiation.

Conclusion: These results indicate that sub- $100 \mathrm{~nm}$ sized $\mathrm{TiO}_{2}$ treatment under ultraviolet $\mathrm{A}$ irradiation induces apoptotic cell death through reactive oxygen species-mediated upregulation of the death receptor, Fas, and activation of the preapoptotic protein, Bax. Elucidating the molecular mechanisms by which nanosized particles induce activation of cell death signaling pathways would be critical for the development of prevention strategies to minimize the cytotoxicity of nanomaterials.

Keywords: $\mathrm{TiO}_{2}$, reactive oxygen species, apoptotic cell death, Fas upregulation, Bax activation, mitochondrial membrane potential loss, caspase activation

\section{Introduction}

In recent years, advances in nanotechnology have been attributed to an increase in the production of nanomaterials. Nanomaterials have physical and chemical properties very different from those of bulk materials, even though they have the same chemical composition. The most important property of nanomaterials is their size, ranging from individual atoms and molecules to microscaled materials. ${ }^{1,2}$ The size and surface area of materials are crucial characteristics from a toxicological perspective. ${ }^{3-5}$ Because nanomaterials have an increased surface area compared with bulk materials, nanomaterials are expected to be more reactive and have more interaction with living organisms.

One of the widely used nanomaterials is titanium dioxide $\left(\mathrm{TiO}_{2}\right)$ that is utilized as a white pigment for making paints, as a food colorant, and in plastics in its bulk form. 
As the demand for nanomaterials increases, nanosized $\mathrm{TiO}_{2}$ is used increasingly in cosmetics, especially for sunscreens, and as a photocatalyst in many industrial fields. Recently, it has become evident that some nanomaterials, including $\mathrm{TiO}_{2}$, have considerable biological activity and cytotoxic effects in normal cells. Previous studies have shown that nanosized $\mathrm{TiO}_{2}$ induces oxidative stress-mediated toxicity in many cell types. However, the molecular mechanism for the cytotoxic effects of nanosized $\mathrm{TiO}_{2}$ has yet to be defined. Several cellular stressors, including anticancer drugs and chemo preventive agents, disturb the natural oxidation and reduction equilibrium in cells via various mechanisms, which involve complex redox (reduction-oxidation) reactions with endogenous oxidants and cellular antioxidant systems. These stressors lead to an increase in reactive oxygen species by a variety of redox enzymes, including flavoprotein-dependent super oxide-producing enzymes such as NADPH oxidase, ${ }^{6,7}$ or by mitochondrial electron transport chain dysfunction. ${ }^{8}$ In recent years, it has become apparent that reactive oxygen species play an important role during induction of apoptotic cell death. ${ }^{9}$ Several studies have provided evidence that intracellular production of reactive oxygen species can lead directly to activation of mitochondrial permeability transition, loss of mitochondrial membrane potential, and cytochrome c release from mitochondria into the cytoplasm, followed by activation of the caspase cascade, and, ultimately, apoptotic cell death. ${ }^{10}$

Further, according to the recent literature, various physicochemical properties of nanoparticles contribute to the cytotoxic mechanisms of nanoparticles. Because commonly used chemicals in aqueous media are unchanged during the exposure time and their intrinsic properties are well understood, treatment conditions, such as concentration and exposure time, provide sufficient information to produce reproducible and reliable dose-response relationships for the corresponding compound. ${ }^{11-13}$ In contrast, in the case of nanoparticles, various physicochemical characteristics (eg, hydrodynamic size distribution, surface charge, and dispersibility in cell culture media) can be drastically changed during the exposure time, making it difficult to generate a reproducible and reliable toxicity response and mechanism for nanoparticles. For instance, due to the differences in their dispersibility in cell culture media, nanoparticles can be highly agglomerated and sedimented, thereby causing a higher dose to adherent cells via gravitational settling as well as diffusion processes. However, when nanoparticles are well dispersed in cell culture media, they are transported to adherent cells only via a diffusion process and thereby provide a less effective dose to cells. ${ }^{14}$ Additionally, due to the significant differences in their hydrodynamic sizes, the highly agglomerated nanoparticles are sedimented more on top of the adherent cells and may have completely different cellular uptake and cytotoxicity profiles, compared with those of well suspended nanoparticles. ${ }^{15-17}$ Thus, to have a more clear understanding of the cytotoxic mechanisms of nanoparticles, it is necessary to investigate the toxicity mechanisms in well characterized nanoparticles as well, together with reasonable control of those key physicochemical properties. ${ }^{11-14}$

Although $\mathrm{TiO}_{2}$ is widely used to make cosmetics and in sunscreens, $\mathrm{TiO}_{2}$ is known to be excited by ultraviolet light and to generate reactive oxygen species in aqueous solution. ${ }^{18}$ In this study, we found that $\mathrm{TiO}_{2}{ }^{\mathrm{P} 25-70}$ nanoparticles with a hydrodynamic size distribution centered around $70 \mathrm{~nm}$ are stable without agglomeration and sedimentation for more than a week, compared with bigger sizes of nanoparticles, ie, the $\mathrm{TiO}_{2}{ }^{\mathrm{P} 25-300}$ and $\mathrm{TiO}_{2}{ }^{\mathrm{P} 25-130}$ fractions. Therefore, we examined the molecular basis for the biological activity and cytotoxicity of nanosized $\mathrm{P} 25 \mathrm{TiO}_{2}$ nanoparticles with a hydrodynamic size distribution centered around $70 \mathrm{~nm}$ $\left(\mathrm{TiO}_{2}{ }^{\mathrm{P} 25-70}\right)$ under ultraviolet $\mathrm{A}$ irradiation. We found that treatment of normal human cells with $\mathrm{TiO}_{2}{ }^{\mathrm{P} 25-70}$ under ultraviolet $\mathrm{A}$ irradiation induced apoptotic cell death via reactive oxygen species-dependent upregulation of the death receptor, Fas, and activation of the preapoptotic protein, Bax, in human normal cells. Elucidating the molecular mechanisms by which nanosized particles induce activation of cell death signaling pathways is critical for the development of prevention strategies to protect against cytotoxicity when using nanomaterials.

\section{Materials and methods Preparation of $\mathrm{TiO}_{2}$ nanoparticle dispersions}

P25 $\mathrm{TiO}_{2}$ powder (Aeroxide $\mathrm{TiO}_{2}$, Evonik Degussa $\mathrm{GmbH}$, Germany) was dispersed to $10 \mathrm{~g} / \mathrm{L}$ in deionized water and was then sonicated for 10 minutes using a probe sonicator $(420 \mathrm{~W}$, $20 \mathrm{kHz}$, Sonosmasher, Ulsso Hitech, South Korea).

The $\mathrm{pH}$ of the dispersed $\mathrm{TiO}_{2}$ stock suspension was approximately 3.6 at an initial concentration of $10 \mathrm{~g} / \mathrm{L}$. The $\mathrm{TiO}_{2}$ suspension was distributed to various sizes by differential speed of centrifugation; $\mathrm{TiO}_{2}$ stock suspension $(20 \mathrm{~mL})$ was centrifuged at 0 or $4000(6570 \times \mathrm{g})$ or 6000 $(9870 \times \mathrm{g}) \mathrm{rpm}$ for 20 minutes using a high-speed centrifuge (Mega 17R, Hanil Science Industrial, Gyeyang-gu Incheon, Korea), and the supernatant $(15 \mathrm{~mL})$ was carefully taken and designated as $\mathrm{TiO}_{2}{ }^{\mathrm{P} 25-300}, \mathrm{TiO}_{2}{ }^{\mathrm{P} 25-130}$, and $\mathrm{TiO}_{2}{ }^{\mathrm{P} 25-70}$, respectively. ${ }^{19}$ 


\section{Characterization of $\mathrm{TiO}_{2}$ nanoparticles}

The morphology and size distribution of the $\mathrm{TiO}_{2}$ nanoarticles were analyzed using images of the nanoparticles and their aggregates taken by scanning electron microscopy (SU-70, Hitachi, Tokyo, Japan). The titanium concentration in the suspension was determined by inductively coupled plasma mass spectrometry (Elan 6100, Perkin-Elmer Sciex, Waltham, MA) after acid digestion procedure with mixtures of $\mathrm{HNO}_{3}$, $\mathrm{HCl}$, and $\mathrm{HF}$. The hydrodynamic size of $\mathrm{TiO}_{2}$ nanoparticles in aqueous media was measured using a dynamic light scattering instrument (Scattero scope I, Qudix Inc, Seoul, South Korea), while the zeta potential was measured by a zetasizer (Nano-ZS, Malvern Instruments, Worcestershire, UK). Relative amounts of the anatase and rutile phases were estimated by their powder $\mathrm{x}$-ray diffraction patterns, as measured using a Rigaku x-ray diffraction instrument (D/max-2000, Rigaku Corporation, Tokyo, Japan). The surface area of the $\mathrm{TiO}_{2}$ powder was determined by multipoint Brunauer-EmmettTeller analysis (nano porosity, Mirae Ultrasonic Tech Co, Bucheon Si, South Korea).

\section{Cell culture, antibodies, and transfection of siRNA}

Chang (normal human liver), MCF10A (normal breast epithelial), and WI38 (normal lung fibroblast) cell lines were obtained from the American Type Culture Collection (Manassas, VA). The cells were grown in Roswell Park Memorial Institute (RPMI) 1640 medium supplemented with $10 \%$ fetal bovine serum, 100 units $/ \mathrm{mL}$ penicillin, and $100 \mu \mathrm{g} / \mathrm{mL}$ streptomycin at $37^{\circ} \mathrm{C}$ in $5 \% \mathrm{CO}_{2}$.

Polyclonal antibodies specific for Bcl-2, Bcl-xL, apoptosis-inducing factor, cytochrome c, caspase-8, caspase-9, caspase-3, $\alpha$-tubulin, HSP60, DR4, and DR5, as well as monoclonal antibodies specific for Bax, Fas, and tumor necrosis factor receptor were purchased from Santa Cruz Biotechnology Inc (Santa Cruz, CA). $\beta$-actin was from Sigma (St Louis, MO). Monoclonal anti-Bak, anti-Bax, and anti-PARP antibodies were from BD Pharmingen (Franklin Lakes, NJ). All small interfering RNA duplexes were purchased from Samchully Pharmaceutical Co, Ltd (Seoul, Korea). Specific siRNA targeting of Bax (5'-CCGAGGCAGCUGACAUGTT-3'), Fas ( $5^{\prime}$-AAGUGCAAGUGCAAACCAGAC- $\left.3^{\prime}\right)$, or green fluorescent protein (5'-CCACTACCTGAGCACCCAG-3') was introduced to Chang cells using the transfection reagent, Lipofectamine $^{\circledR}$ (Invitrogen, Carlsbad, CA), following the manufacturer's recommendations. siRNA targeted to green fluorescent protein was used as the negative control.

\section{Ultraviolet $A$ irradiation of $\mathrm{TiO}_{2}$-treated cells}

For treatment of cells, $\mathrm{TiO}_{2}$ nanoparticles were added to the cell culture medium at a concentration of $150 \mathrm{ppm}$. Cells were then irradiated with ultraviolet A ( $0.75 \mathrm{~J} /$ hour $)$ using a Sankyo Denki lamp (FL20SBL, Nagano, Japan). After culture for 24 hours, the cells were harvested for further analysis.

\section{Quantification of cell death}

Cell death was analyzed using both propidium iodide staining and an Annexin $\mathrm{V}$ labeling kit according to the manufacturer's recommendations (Sigma). For assessment of cell death, the cells were plated onto $60 \mathrm{~mm}$ dishes at a cell density of $2 \times 10^{5}$ cells per dish and treated with $\mathrm{TiO}_{2}$ the following day. At indicated time points, the cells were harvested and washed in phosphate buffer solution. Annexin V-positive early apoptotic cells or propidium iodide-positive cells were then quantified using a FACScan flow cytometer fitted with Cell Quest software (BD Biosciences, Franklin Lakes, NJ).

\section{Measurement of reactive oxygen species generation}

Briefly, the cells were incubated in $40 \mathrm{nM}$ 3,3-dihexyloxacarboxyanine iodide [DiOC6(3)] or $10 \mathrm{nM}$ 2,7-dichlorodihydrofluorescein diacetate (DCFH-DA, Molecular Probes, Eugene, OR) at $37^{\circ} \mathrm{C}$ for 15 minutes and washed with cold phosphate buffer solution three times. The retained $\mathrm{DiOC}_{6}(3)$ and DCFH-DA was analyzed using a flow cytometer fitted with Cell Quest Pro software (Becton Dickinson, Franklin Lakes, NJ). For MitoSox Red staining, the cells were fixed with $4 \%$ paraformaldehyde and permeabilized with $0.1 \%$ Triton X-100 in phosphate buffer solution. Following fixation, the cells were incubated with MitoSox Red in phosphate buffer solution. The stained cells were then visualized using a fluorescence microscope (Olympus IX71) and quantified by flow cytometry.

\section{Flow cytometric analysis of Bax and Bak activation}

After fixation in $0.25 \%$ paraformaldehyde for 5 minutes and washing with phosphate buffer solution, the cells were incubated for 30 minutes in the presence of digitonin $100 \mu \mathrm{g} / \mathrm{mL}$ with antibodies recognizing the $\mathrm{N}$-terminal epitopes of Bax (clone 6A7, BD Pharmingen) or Bak (AM03TC100, Oncogene Research Products). After incubation with a fluorescein isothiocyanate-conjugated anti mouse antibody 
for 30 minutes, the cells $(10,000$ per sample) were analyzed by flow cytometry.

\section{Western blot analysis}

Cell lysates were prepared by extracting proteins with lysis buffer (40 mM Tris-HCl [pH 8.0], $120 \mathrm{mM} \mathrm{NaCl}$, $0.1 \%$ Nonidet-P40) supplemented with protease inhibitors. Proteins were separated by sodium dodecyl sulfatepolyacrylamide gel electrophoresis and transferred to a nitrocellulose membrane (Amersham Biosciences, Arlington Heights, IL). The membrane was blocked with 5\% nonfat dry milk in Tris-buffered saline and incubated with primary antibodies overnight at $4^{\circ} \mathrm{C}$. Blots were developed using a peroxidase-conjugated secondary antibody, and the proteins were visualized by enhanced chemiluminescence (Amersham Biosciences), using the manufacturer's protocol.

\section{Preparation of cytosolic and mitochondrial fractions}

Cells were washed with ice-cold phosphate buffer solution, left on ice for 10 minutes, and then resuspended in isotonic homogenization buffer $(250 \mathrm{mmol} / \mathrm{L}$ sucrose, $10 \mathrm{mmol} / \mathrm{L} \mathrm{KCl}, 1.5 \mathrm{mmol} / \mathrm{L} \mathrm{MgCl}_{2}, 1 \mathrm{mmol} / \mathrm{L} \mathrm{Na}-\mathrm{EDTA}$, $1 \mathrm{mmol} / \mathrm{L} \mathrm{Na-EGTA}, 1 \mathrm{mmol} / \mathrm{L}$ dithiothreitol, $0.1 \mathrm{mmol} / \mathrm{L}$ phenylmethylsulfonylfluoride, and $10 \mathrm{mmol} / \mathrm{L}$ Tris- $\mathrm{HCl}[\mathrm{pH}$ 7.4]) containing a proteinase inhibitor mixture (Roche, Basel, Switzerland). Cells were then disrupted by a Dounce homogenizer at 80 strokes. The unbroken cells were excluded by spinning down at $30 \mathrm{~g}$ for 5 minutes. The mitochondrial fractions were then obtained by serial centrifugation of the supernatant at $750 \mathrm{~g}$ for 10 minutes and $14,000 \mathrm{~g}$ for 20 minutes, taking the supernatant at each step. For cytosolic fractionation, the cells were disrupted by a loose homogenizer at 10 strokes, and serially centrifuged at $750 \mathrm{~g}$ for 10 minutes and 14,000 g for 20 minutes, taking the supernatant at each step.

\section{Cross-linking of $\mathrm{Bax}$ and Bak proteins}

Cells were permeabilized at room temperature with $0.015 \%-0.02 \%$ digitonin for $1-2$ minutes in an isotonic buffer (10 mM HEPES, $150 \mathrm{mM} \mathrm{NaCl}, 1.5 \mathrm{mM} \mathrm{MgCl}, 1 \mathrm{mM}$ EGTA, $\mathrm{pH}$ 7.4) containing protease inhibitors. The permeabilized cells were then scraped at $4^{\circ} \mathrm{C}$ and incubated with cross-linker (dissuccinimidyl suberate, with linker lengths of $11.4 \AA$ ) on a head-to-head rocker for 30 minutes at room temperature. The unreacted cross-linkers were quenched with a $1 / 10$ volume of $2 \mathrm{M}$ Tris- $\mathrm{HCl}(\mathrm{pH} 7.4)$ for another 30 minutes at room temperature, with rocking. The permeabilized and cross-linker-treated cells were then centrifuged at $15,000 \mathrm{~g}$ for 10 minutes at $4^{\circ} \mathrm{C}$. The supernatant was taken for cytosol proteins and the pellet was further lysed with ice-cold lysis buffer, ie, 2\% 3-[(3-cholamidopropyl)dimethylammonio]-1-propanesulfonate containing protease inhibitors, for 60 minutes at $4^{\circ} \mathrm{C}$ to determine the membrane fraction. For this, a nondenaturing loading buffer was added before running sodium dodecyl sulfate-polyacrylamide gel electrophoresis.

\section{Statistical analysis}

Data were analyzed using the unpaired two-tailed Student's $t$-test. Data were expressed as the mean \pm standard error of the mean derived from at least three independent experiments. Differences were considered statistically significant at $P<0.005$.

\section{Results and discussion Physicochemical characteristics of $\mathrm{TiO}_{2}$ nanoparticles and dispersions}

Based on our scanning electron microscopy and x-ray diffraction measurements, the $\mathrm{P} 25 \mathrm{TiO}_{2}$ powder had a primary particle size of approximately $21 \mathrm{~nm}$ and was composed mainly of anatase $(87 \%)$ and rutile $(13 \%)$ crystalline phase. The Brunauer-Emmett-Teller specific surface area was $57 \mathrm{~m}^{2} / \mathrm{g}$ and the point-of-zero charge was estimated to be in the vicinity of $\mathrm{pH} 5.8$. These basic characteristics agree well with those provided by the manufacturer and by previous studies. ${ }^{20-22}$ In this study, we divided the P25 $\mathrm{TiO}_{2}$ suspension into three fractions with different hydrodynamic size distributions. To this end, the primary P25 $\mathrm{TiO}_{2}$ suspension was centrifuged using different speeds ( 0 , $4000,6000 \mathrm{rpm})$. $\mathrm{TiO}_{2}$ nanoparticles with different hydrodynamic size distributions were then obtained by taking the supernatant and designating it according to hydrodynamic sizes of $327 \mathrm{~nm}$ (without fractionation, $\mathrm{TiO}_{2}{ }^{\mathrm{P} 25-300}$ ), $133 \mathrm{~nm}$ (fractionated at $4000 \mathrm{rpm}, \mathrm{TiO}_{2}{ }^{\mathrm{P} 25-130}$ ), and $74 \mathrm{~nm}$ (fractionated at $6000 \mathrm{rpm}, \mathrm{TiO}_{2}{ }^{\mathrm{P} 25-70}$ ). The $\mathrm{TiO}_{2}{ }^{\mathrm{P} 25-300}$ fraction was mainly composed of heavily agglomerated/aggregated particles, while $\mathrm{TiO}_{2}{ }^{\mathrm{P} 25-130}$ and $\mathrm{TiO}_{2}{ }^{\mathrm{P} 25-70}$ were composed of much smaller agglomerates/aggregates (Figure 1). The sub-100 nm fraction (ie, $\mathrm{TiO}_{2}{ }^{\mathrm{P} 25-70}$ ) was found to be stable without agglomeration and sedimentation for more than a week, whereas the $\mathrm{TiO}_{2}{ }^{\mathrm{P} 25-300}$ and $\mathrm{TiO}_{2}{ }^{\mathrm{P} 25-130}$ fractions were easily aggregated and sedimented in slight acidic conditions ( $\mathrm{pH} 4-5$ ), However, exposure of $\mathrm{TiO}_{2}^{\mathrm{P} 25-70}$ to typical in vitro cell culture medium (eg, RPMI 1640 or Dulbecco's Modified Eagle's Medium) instantly caused strong agglomeration and sedimentation, which has been previously reported to 
A
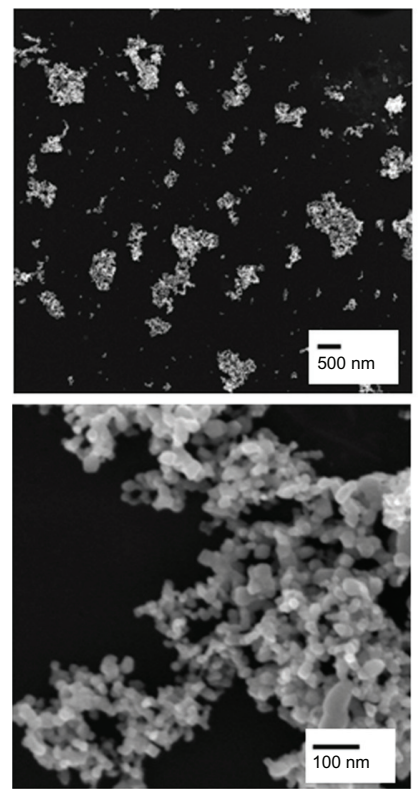

B
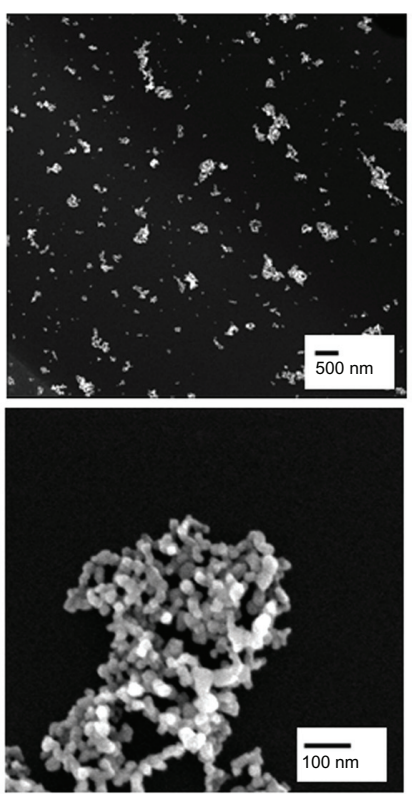

\section{C}
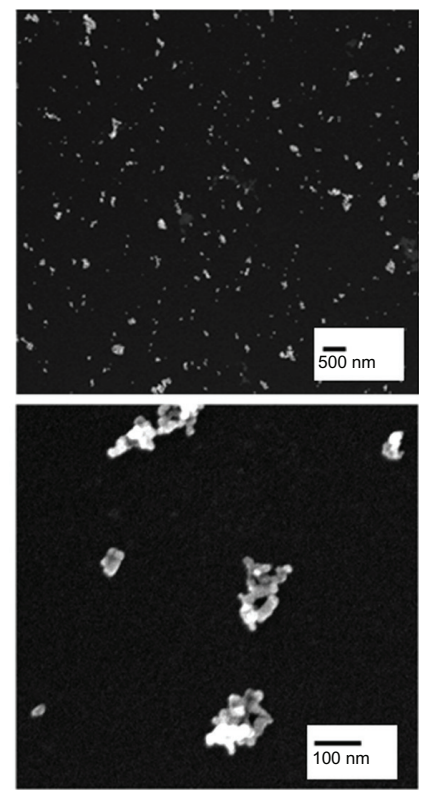

Figure I Representative scanning electron microscopic images of fractionated $\mathrm{TiO}_{2}$ in distilled water. $\mathrm{TiO}_{2}$ suspension in deionized water was fractionated to three different hydrodynamic sizes by differential speed of centrifugation. The supernatant was carefully taken and designated as $\mathrm{TiO}_{2}{ }^{\mathrm{P} 25-300}(\mathbf{A})$, TiO ${ }_{2}^{\mathrm{P} 25-130}(\mathbf{B})$, or $\mathrm{TiO}_{2}{ }^{\mathrm{P} 25-70}(\mathbf{C})$ after centrifugation for 20 minutes at 0 rpm, 4000 rpm (6570 g), or 8000 rpm (9870 g), respectively.

Note: Scale bars indicate $500 \mathrm{~nm}$ (upper) and $100 \mathrm{~nm}$ (lower).

cause problems in performing accurate and reproducible toxicity assessments of nanoparticles. ${ }^{5,23-27}$ To overcome this problem of colloidal instability, nanoparticles are often stabilized with various surface-modifying ligands. ${ }^{19}$ In this study, rather than adding additional surface-modifying compounds, fetal bovine serum (a supplement used for in vitro cell culture) was used as an efficient stabilizing agent. ${ }^{17}$ By monitoring the hydrodynamic size distributions of all three fractions of $\mathrm{TiO}_{2}$ in RPMI media supplemented with fetal bovine serum for 48 hours, we observed that the unfractionated $\mathrm{TiO}_{2}{ }^{\mathrm{P} 25-300}$ increased in hydrodynamic size with aggregation over time and formed micron-sized particles with heavy sedimentation (Figure 2A), whereas the hydrodynamic size of $\mathrm{TiO}_{2}{ }^{\mathrm{P} 25-130}$ and $\mathrm{TiO}_{2}{ }^{\mathrm{P} 25-70}$ were not changed with time, indicating no aggregation of $\mathrm{TiO}_{2}$ (Figure 2B and C). Zeta potential measurements were also performed for all three types of $\mathrm{TiO}_{2}$ in RPMI media with fetal bovine serum, yielding values in the range of -9.42 to $-10.4 \mathrm{mV}$. In addition, the impact of exposure to ultraviolet $\mathrm{A}$ irradiation on the physicochemical properties of $\mathrm{TiO}_{2}$ was also investigated. However, no significant changes in hydrodynamic size, zeta potential, or colloidal stability were observed after exposure to $0.75 \mathrm{~J} /$ hour ultraviolet A irradiation for 48 hours.
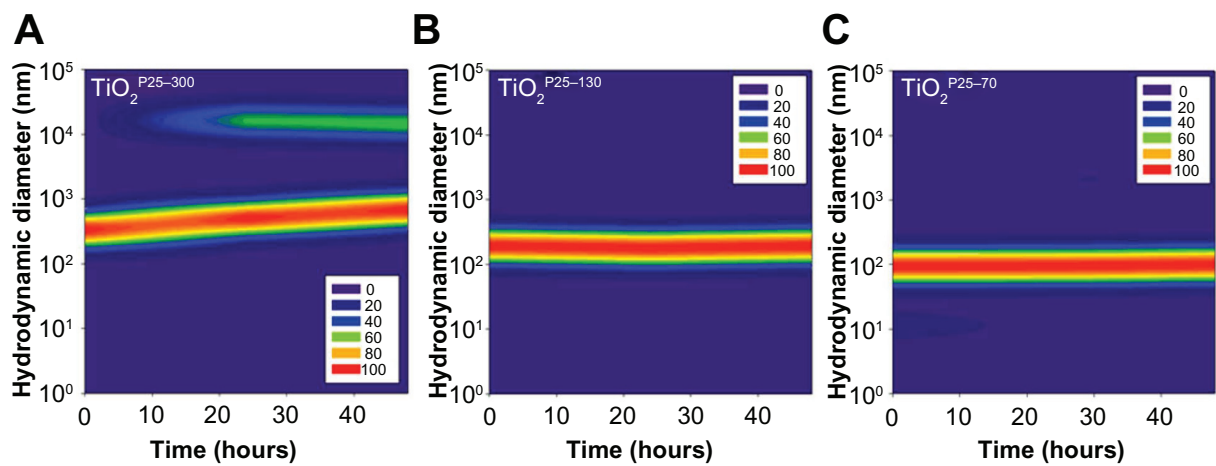

Figure 2 Temporal variations of hydrodynamic size distributions of $\mathrm{TiO}_{2}$ in media supplemented with fetal bovine serum. In the cell culture media, ie, RPMI with I0\% fetal bovine serum, hydrodynamic sizes of $\mathrm{TiO}_{2}$ nanoparticles were monitored for 48 hours. The hydrodynamic size was increased in the unfractionated $\mathrm{TiO}_{2}^{\mathrm{P} 25-300}$ ( $\mathbf{A}$ ) with time and caused micron-sized particles with heavy sedimentation, whereas the hydrodynamic size of $\mathrm{TiO}_{2}{ }^{\mathrm{P} 25-130}(\mathbf{B})$ and $\mathrm{TiO}_{2}{ }^{\mathrm{P} 25-70}(\mathbf{C})$ were not changed with time, indicating no aggregation. 


\section{$\mathrm{TiO}_{2}$ induces hydrodynamic size- dependent apoptosis in normal cells}

To investigate whether $\mathrm{TiO}_{2}$ influences cell death in normal cells, we treated a Chang (normal liver) cell line with $\mathrm{TiO}_{2}$ nanoparticles of different hydrodynamic size distributions $\left(\mathrm{TiO}_{2}{ }^{\mathrm{P} 25-70}, \mathrm{TiO}_{2}{ }^{\mathrm{P} 25-130}\right.$, and $\left.\mathrm{TiO}_{2}{ }^{\mathrm{P} 25-300}\right)$ at various concentrations from 0 to $400 \mathrm{ppm}$ for 24 hours and measured cell death by flow cytometry with propidium iodide staining. As shown in Figure S1, treatment of Chang cells with $\mathrm{TiO}_{2}$ nanoparticles at a concentration lower than $200 \mathrm{ppm}$ did not cause significant cell death, while treatment with a higher concentration (200 and $400 \mathrm{ppm}$ ) caused dramatic cell death at any $\mathrm{TiO}_{2}$ nanoparticle size (Figure $\mathrm{S} 1$ ).

In previous studies, $\mathrm{TiO}_{2}$ has been excited by ultraviolet irradiation and showed cellular toxicity. ${ }^{18}$ Because treatment with $\mathrm{TiO}_{2}$ nanoparticles at a concentration of $150 \mathrm{ppm}$ did not induce cell death, we went on to investigate the synergistic effect of $\mathrm{TiO}_{2}$ nanoparticles and ultraviolet irradiation on cell death in a Chang line. To examine this possibility, we treated the Chang cells with $\mathrm{TiO}_{2}$ nanoparticles $\left(\mathrm{TiO}_{2}{ }^{\mathrm{P} 25-70}\right.$, $\mathrm{TiO}_{2}{ }^{\mathrm{P} 25-130}$, and $\mathrm{TiO}_{2}{ }^{\mathrm{P} 25-300}$ ) in combination with ultraviolet $\mathrm{A}$ irradiation ( $0.75 \mathrm{~J} /$ hour), cultured the cells for 24 hours, and then measured cell death by flow cytometry with propidium iodide staining. As shown in Figure 3A, treatment with $\mathrm{TiO}_{2}$ at a concentration of $150 \mathrm{ppm}$, at which there was no significant cell death (Figure S1), in combination with ultraviolet A, induced cell death in Chang cells in a size-dependent manner; almost $20 \%$ of Chang cells underwent cell death within 24 hours after combined treatment with $\mathrm{TiO}_{2}{ }^{\mathrm{P} 25-70}$ and ultraviolet $\mathrm{A}$ irradiation; $50 \%$ and $80 \%$ underwent cell death after treatment with $\mathrm{TiO}_{2}{ }^{\mathrm{P} 25-130}$ and $\mathrm{TiO}_{2}{ }^{\mathrm{P} 25-300}$ in combination with ultraviolet A irradiation, respectively (Figure 3A). However, treatment with $\mathrm{TiO}_{2}$ at $150 \mathrm{ppm}$ or ultraviolet $\mathrm{A}$ irradiation alone did not cause significant cell death. In addition, combined treatment with $\mathrm{TiO}_{2}$ and ultraviolet $\mathrm{A}$ irradiation induced cell death in normal breast epithelial cells (MCF-10A) and lung fibroblasts (WI38, Figure 3B). Thereafter, we used $\mathrm{TiO}_{2}$ nanoparticles at a concentration of $150 \mathrm{ppm}$ in all experiments. Also, although all three fractions of $\mathrm{TiO}_{2}$ showed cellular toxicity, we undertook further investigations of the mechanism of nanotoxicity only with the smallest sized nanoparticles, ie, the $\mathrm{TiO}_{2}{ }^{\mathrm{P} 25-70}$ fraction, because this fraction may minimize the influence of increased cellular exposure via gravitational settling of the nanoparticles as well as the toxicity mechanisms caused by the heavily agglomerated micron-sized particles.

\section{$\mathrm{TiO}_{2}{ }^{\mathrm{P} 25-70}$ induces apoptosis via upregulation of Fas and activation of caspases}

To determine whether death receptors are involved in the cell death induced by $\mathrm{TiO}_{2}{ }^{\mathrm{P} 25-70}$, we examined changes in death receptor expression levels, including DR4, DR5, Fas, and tumor necrosis factor receptors, in response to $\mathrm{TiO}_{2}{ }^{\mathrm{P} 25-70}$ treatment. As shown in Figure 4A and Figure S2, flow cytometric analysis clearly revealed that the protein levels of Fas were selectively increased by $\mathrm{TiO}_{2}{ }^{\mathrm{P} 25-70}$, but we failed to detect any changes in the expression of tumor necrosis factor receptor or the death receptor (Figure 4B and Figure S2). Moreover, siRNA targeting of Fas clearly attenuated the apoptotic cell death induced by $\mathrm{TiO}_{2}{ }^{\mathrm{P} 25-70}$ (Figure $4 \mathrm{C}$ ). In addition, cyclohexamide, a protein synthesis inhibitor, completely inhibited the Fas expression induced by $\mathrm{TiO}_{2}{ }^{\mathrm{P} 25-70}$ (data not shown), indicating that the Fas protein level was increased via de novo synthesis after treatment with $\mathrm{TiO}_{2}{ }^{\mathrm{P} 25-70}$. Because caspase- 8 is a key player in Fas-mediated apoptotic cell death, we next investigated whether treatment with $\mathrm{TiO}_{2}{ }^{\mathrm{P} 25-70}$ activates caspase-8. As shown in Figure 4D, $\mathrm{TiO}_{2}{ }^{\mathrm{P} 25-70}$ treatment together with ultraviolet A irradiation significantly induced activation of caspase- 8 and subsequently induced
A

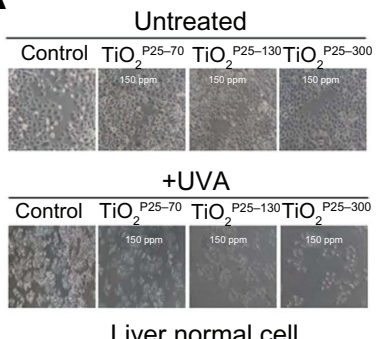

Liver normal cell

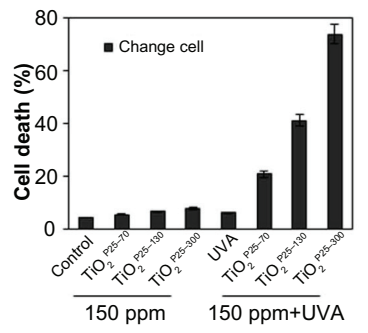

B

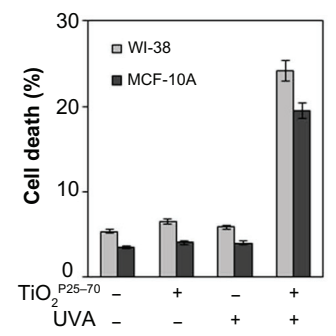

Figure $3 \mathrm{TiO}_{2}$ sensitizes normal cells to ultraviolet A irradiation leading to apoptotic cell death (A and $\left.\mathbf{B}\right)$ Measurement of cell death by FACS analysis after propidium iodide staining. (A) Treatment of Chang cells with $\mathrm{TiO}_{2}$ in combination with UVA irradiation caused cell death in proportion to the size of $\mathrm{TiO}_{2}\left(\mathrm{TiO}_{2}{ }^{\mathrm{P} 25-70}\right.$, $\mathrm{TiO}_{2}{ }^{\mathrm{P} 25-130}$, $\left.\mathrm{TiO}_{2}{ }^{\mathrm{P} 25-300}\right)$, while treatment with $\mathrm{TiO}_{2}$ alone did not induce cell death. (B) Treatment of WI-38 and MCFIOA cells with $\mathrm{TiO}_{2}^{\mathrm{P} 25-70}$ in combination with ultraviolet A irradiation caused cell death, while treatment with either $\mathrm{TiO}_{2}$ or ultraviolet $\mathrm{A}$ alone did not induce cell death.

Abbreviations: UVA, ultraviolet A; WI-38, normal lung fibroblast cell line; MCFIOA, normal breast epithelial cell line. 
A

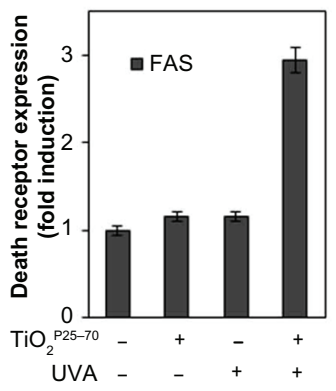

C

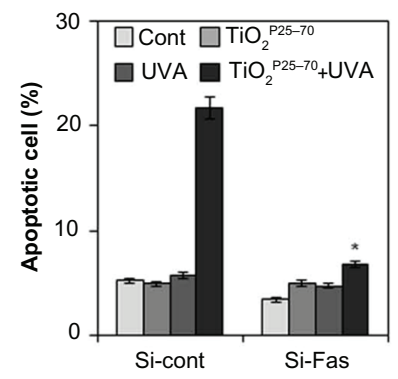

B
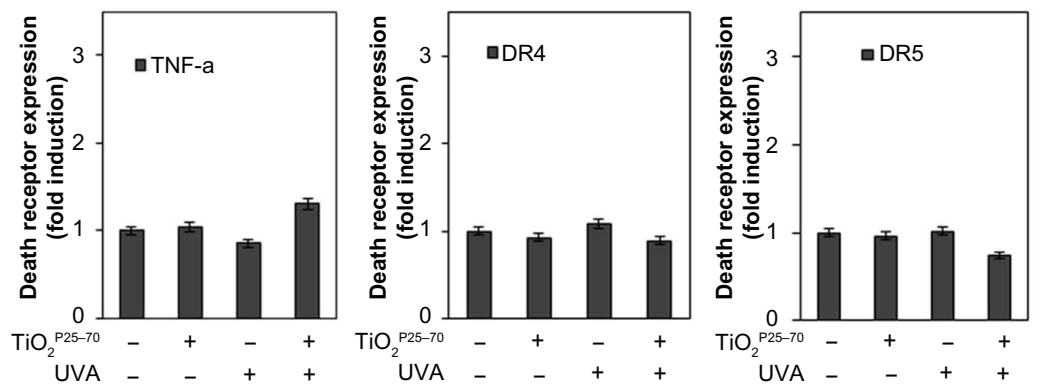

E

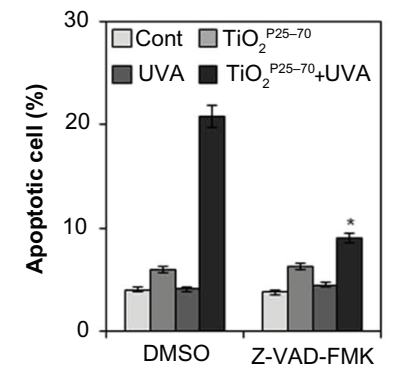

Figure $4 \mathrm{TiO}_{2}{ }^{\mathrm{P} 25-70}$ induces apoptotic cell death through upregulation of Fas and subsequent activation of caspases. (A) Flow cytometry analysis reveals upregulation of Fas expression in Chang cells treated with $\mathrm{TiO}_{2}{ }^{\mathrm{P} 25-70}$ in combination with ultraviolet $\mathrm{A}$ irradiation, while treatment with either $\mathrm{TiO}_{2}{ }^{\mathrm{P} 25-70}$ or ultraviolet $\mathrm{A}$ alone did not upregulate the level of Fas expression. (B) Expression levels of other death receptors, f, TNFR, DR4, and DR5, were not altered in Chang cells by combined treatment with TiO 2 P25-70 and ultraviolet A. (C) Measurement of cell death by FACS analysis after double staining with propidium iodide and Annexin V. Pretreatment with siRNA targeted to Fas suppressed $\mathrm{TiO}_{2}{ }^{\mathrm{P} 25-70}$-induced cell death. (D) Treatment of Chang cells with $\mathrm{TiO}_{2}{ }^{\mathrm{P} 25-70}$ in combination with ultraviolet $\mathrm{A}$ decreased the proform of caspase-8 and increased the cleaved form of caspase-3 and PARP. (E) Measurement of cell death by FACS analysis after double staining with propidium iodide and Annexin V. Pretreatment with a broad-spectrum caspase inhibitor, z-VAD-fmk, attenuated cell death induced by combined treatment with $\mathrm{TiO}_{2}{ }^{\mathrm{P} 25-70}$ and ultraviolet $\mathrm{A}$.

Notes: $* P<0.005$. Error bars represent the mean \pm standard deviation of triplicate samples.

Abbreviations: DMSO, dimethylsulfoxide; TNF, tumor necrosis factor; DR, death receptor; UVA, ultraviolet; PARP, poly (ADP-ribose) polymerase.

activation of caspase-3 and cleavage of PARP-1. In addition, a broad-spectrum caspase inhibitor, z-VAD-fmk, completely attenuated the apoptotic cell death induced by $\mathrm{TiO}_{2}{ }^{\mathrm{P} 25-70}$ (Figure 4E). Taken together, these results suggest that $\mathrm{TiO}_{2}{ }^{\mathrm{P} 25-70}$ induces apoptotic cell death in normal cells via Fas upregulation and subsequent caspase activation.

\section{Conformational activation of Bax is required for mitochondrial dysfunction and apoptotic cell death induced by $\mathrm{TiO}_{2}{ }^{\mathrm{P} 25-70}$}

To determine whether the mitochondrial pathway is involved in the cell death caused by $\mathrm{TiO}_{2}{ }^{\mathrm{P} 25-70}$, we examined changes in mitochondrial membrane potential and release of proapoptotic molecules from the mitochondria upon treatment with $\mathrm{TiO}_{2}{ }^{\mathrm{P} 25-70}$. As shown in Figure 5A, treatment with $\mathrm{TiO}_{2}{ }^{\mathrm{P} 25-70}$ under ultraviolet $\mathrm{A}$ irradiation induced significant loss of mitochondrial membrane potential. Cytosolic cytochrome $\mathrm{c}$ and apoptosis-inducing factor were markedly increased in response to treatment with $\mathrm{TiO}_{2}{ }^{\mathrm{P} 25-70}$ (Figure 5B), coinciding with changes in the mitochondrial membrane potential. Moreover, caspase-9 was activated by treatment with $\mathrm{TiO}_{2}{ }^{\mathrm{P} 25-70}$ (Figure 5C). These results indicate that $\mathrm{TiO}_{2}{ }^{\mathrm{P} 25-70}$ induces dissipation of the mitochondrial membrane potential and release of proapoptotic molecules.

Because it has been demonstrated that proapoptotic Bcl-2 family members, especially Bax and Bak, are crucial to mitochondrial cell death pathways, ${ }^{28,29}$ we next analyzed activation of Bax and/or Bak after treatment with $\mathrm{TiO}_{2}{ }^{\mathrm{P} 25-70}$. By flow cytometry analysis with antibodies recognizing N-terminal epitopes of Bax or Bak, we found that treatment comprising $\mathrm{TiO}_{2}{ }^{\mathrm{P} 25-70}$ and ultraviolet $\mathrm{A}$ irradiation induces conformational change and mitochondrial relocalization of Bax from the cytosol (Figure 5D), but not Bak (Figure 5E). Moreover, knockdown of Bax with specific siRNA attenuated the apoptotic cell death induced by $\mathrm{TiO}_{2}{ }^{\mathrm{P} 25-70}$ (Figure 5F). These results indicate that conformational activation of Bax plays a crucial role in mitochondrial potential loss and subsequent cell death induced by $\mathrm{TiO}_{2}^{\mathrm{P} 25-70}$. 
A

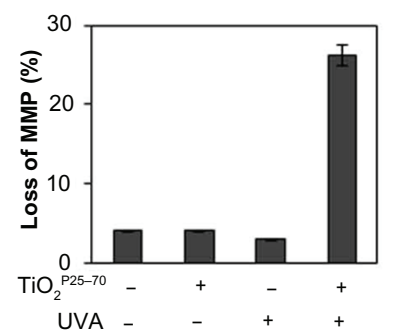

B

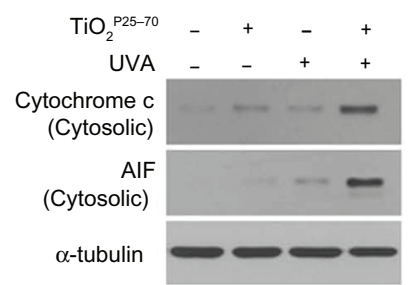

C



D

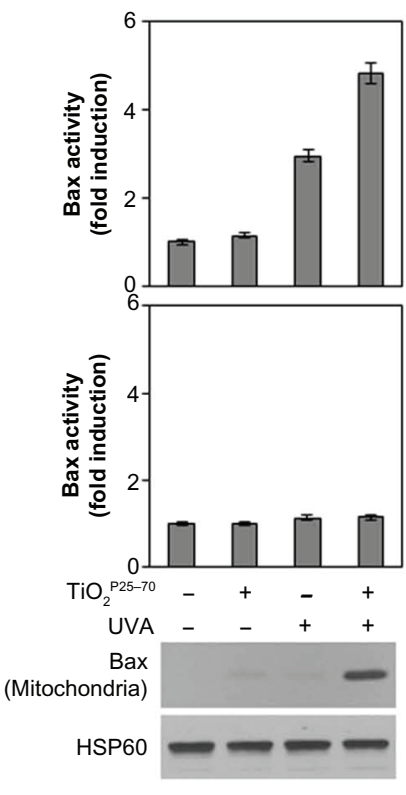

E
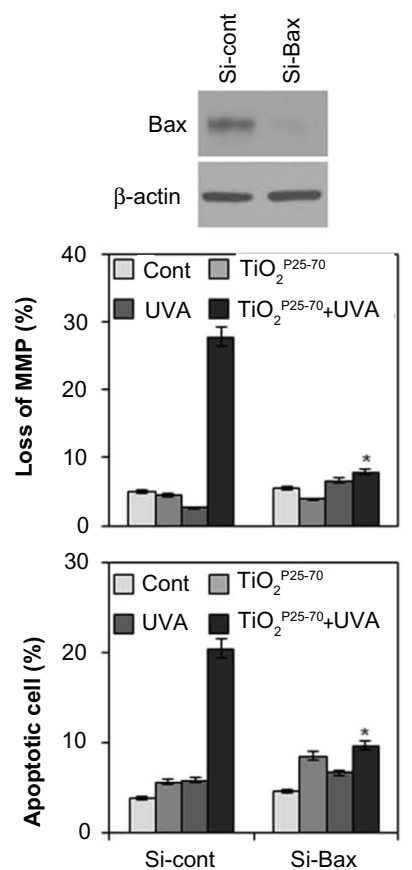

Figure 5 Conformational activation of $\mathrm{Bax}$ is required for $\mathrm{TiO}_{2}{ }^{\mathrm{P} 5}-70$-induced mitochondrial dysfunction and apoptotic cell death. Combined treatment with $\mathrm{TiO}_{2}{ }^{\mathrm{P} 25-70}$ and ultraviolet $\mathbf{A}$ induced mitochondrial membrane potential loss $(\mathbf{A})$ and release of cytochrome $\mathbf{c}$ and apoptosis-inducing factor to cytosol (B) and the decrease of proform caspase-9 (C) in Chang cells. Mitochondrial membrane potential of cells was determined by retention of $\mathrm{DiOC}_{6}(3)$. The amount of retained DiOC 6 ( 3$)$ was measured by flow cytometry. (D) Measurement of Bax and Bak expression levels by FACS and western blot analysis. Bax expression was induced in mitochondria-enriched membrane fractions of Chang cells when treated with combination of $\mathrm{TiO}_{2}{ }^{\mathrm{P} 25-70}$ and ultraviolet A irradiation, whereas Bak was not induced. (E) Pretreatment with siRNA targeting of Bax attenuated mitochondrial membrane potential loss (upper) and cell death (lower) induced by combination treatment of TiO ${ }_{2}^{\mathrm{P} 25-70}$ and ultraviolet $\mathrm{A}$ irradiation. Cell death was measured by FACS analysis after double staining with propidium iodide and Annexin V.

Notes: $* P<0.005$. Error bars represent the mean \pm standard deviation of triplicate samples.

Abbreviations: UVA, ultraviolet A; AIF, apoptosis-inducing factor; MMP, matrix metalloproteinase.

\section{Reactive oxygen species are involved in Fas upregulation, Bax activation, and apoptosis-induced by $\mathrm{TiO}_{2}{ }^{\mathrm{P} 25-70}$}

Oxidative damage is often implicated in apoptotic cell death. ${ }^{30,31}$ We therefore subsequently examined changes in intracellular reactive oxygen species levels in Chang cells treated with $\mathrm{TiO}_{2}{ }^{\mathrm{P} 25-70}$. As shown in Figure 6A, treatment with $\mathrm{TiO}_{2}{ }^{\mathrm{P} 25-70}$ under ultraviolet $\mathrm{A}$ irradiation led to an approximately threefold increase in mean $2^{\prime}, 7^{\prime}$-dichlorofluorescein fluorescence, indicating an increase of intracellular reactive oxygen species. To confirm further a link between elevation of intracellular reactive oxygen species and mitochondrial cell death, the cells were preincubated with N-acetyl-L-cysteine, an antioxidant, prior to $\mathrm{TiO}_{2}{ }^{\mathrm{P} 25-70}$ treatment. Treatment of $\mathrm{TiO}_{2}{ }^{\mathrm{P} 25-70}$ did not induce cell death in the presence of N-acetyl-L-cysteine (Figure 6B). Pretreatment of N-acetyl-L-cysteine also inhibited $\mathrm{TiO}_{2}{ }^{\mathrm{P} 25-70}$-induced Fas upregulation and caspase-8 activation (Figure 6C). Moreover, N-acetyl-L-cysteine clearly inhibited conformational change and mitochondrial redistribution of $\mathrm{Bax}$ induced by $\mathrm{TiO}_{2}^{\mathrm{P} 25-70}$ (Figure 6D), mitochondrial membrane potential loss (Figure 6E), and apoptosis-inducing factor and cytochrome $\mathrm{c}$ release (Figure $6 \mathrm{E}$ ). These observations suggest that an increase in intracellular reactive oxygen species is critically required for $\mathrm{TiO}_{2}{ }^{\mathrm{P} 25-70}$-induced Fas upregulationmediated and Bax activation-mediated apoptotic cell death.

To determine further whether the mitochondria contribute to increased intracellular reactive oxygen species generation induced by $\mathrm{TiO}_{2}^{\mathrm{P} 25-70}$, we utilized MitoSox Red, a mitochondrial reactive oxygen species detection reagent, in conjunction with fluorescence microscopy. As shown in Figure $6 \mathrm{~F}, \mathrm{TiO}_{2}{ }^{\mathrm{P} 25-70}$ together with ultraviolet $\mathrm{A}$ irradiation induced an increase in mitochondrial fluorescence, which is very similar to the observed increase in $\mathrm{CM}-\mathrm{H}_{2} \mathrm{DCFDA}$ fluorescence. The stippled linear pattern of fluorescence in Chang cells loaded with MitoSox Red is consistent with mitochondrial localization of reactive oxygen species. Taken together, these results suggest that the mitochondria may contribute to the overall elevation in reactive oxygen species production in Chang cells treated with $\mathrm{TiO}_{2}{ }^{\mathrm{P} 25-70}$. 
A

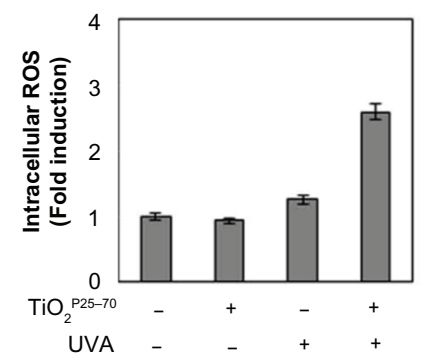

D

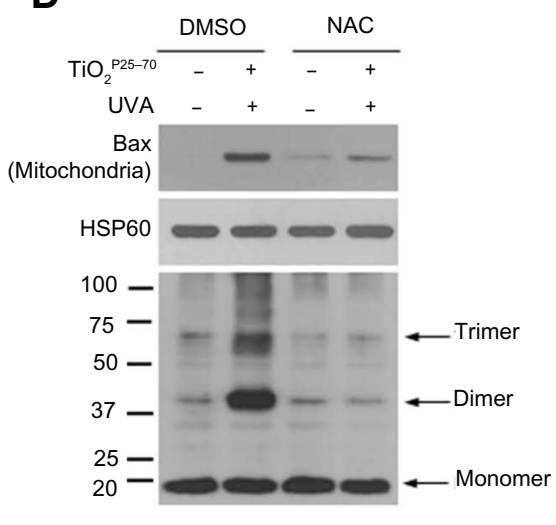

B

E
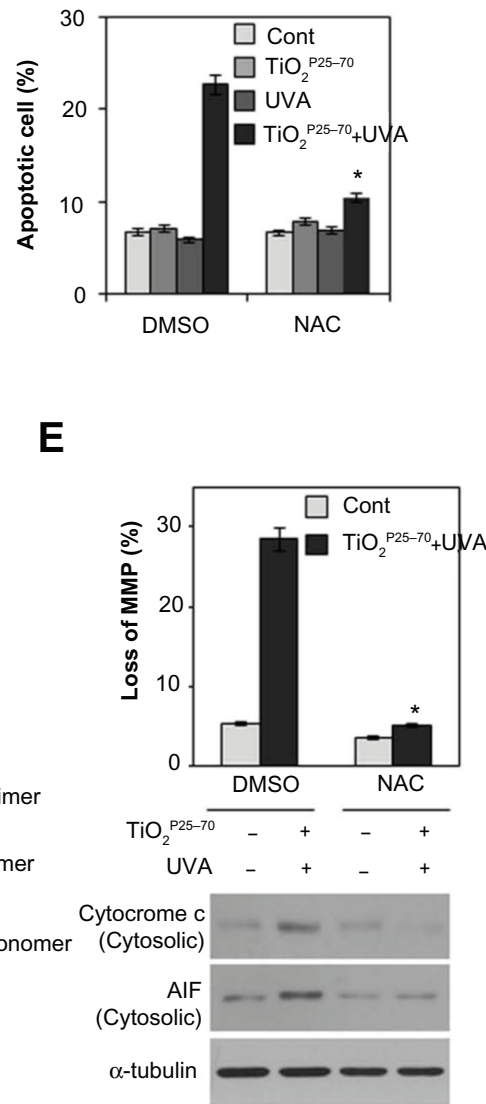

C

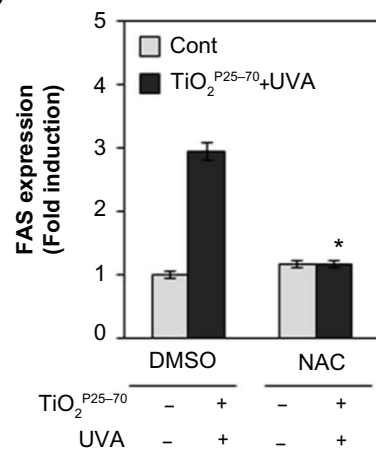

Caspase 8

$\beta$-actin

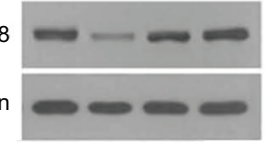

F

Control

$\mathrm{TiO}_{2}{ }^{\mathrm{P} 25-70}$

UVA

$\mathrm{TiO}_{2}{ }^{\mathrm{P} 25-70}+\mathrm{UVA}$

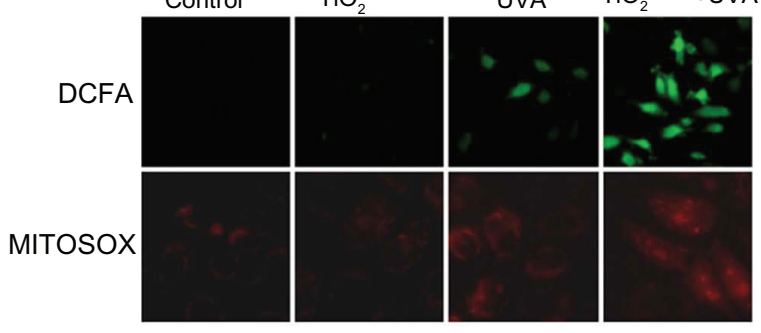

Figure 6 Reactive oxygen species are critically involved in the $\mathrm{TiO}_{2}{ }^{\mathrm{P} 25-70}$-induced Fas upregulation, Bax activation, and apoptotic cell death. (A) Measurement of intracellular reactive oxygen species levels by FACS analysis. Combined treatment of Chang cells with $\mathrm{TiO}_{2}{ }^{\mathrm{P} 25-70}$ and ultraviolet $\mathrm{A}$ irradiation increased intracellular reactive oxygen species levels, whereas single treatment with either $\mathrm{TiO}_{2}{ }^{\mathrm{P} 25-70}$ or ultraviolet $\mathrm{A}$ had no effect on intracellular reactive oxygen species levels. (B) Pretreatment with the antioxidant, $\mathrm{N}$-acetyl-L-cysteine, attenuated cell death induced by combined treatment with $\mathrm{TiO}_{2}{ }^{\mathrm{P} 5-70}$ and ultraviolet $\mathrm{A}$ irradiation. Cell death was measured by $\mathrm{FACS}$ analysis after double staining with propidium iodide and Annexin V. (C) Pretreatment with antioxidant, $\mathrm{N}$-acetyl-L-cysteine attenuated FAS expression (upper) and suppressed the increase of proform, caspase-8 (lower). (D) Pretreatment with $\mathrm{N}$-acetyl-L-cysteine attenuated oligomerization of Bax in mitochondria-enriched membrane fractions of Chang cells treated with combination of $\mathrm{TiO}_{2}{ }^{\mathrm{P} 25-70}$ and ultraviolet $\mathrm{A}$. (E) Pretreatment with $\mathrm{N}$-acetyl-L-cysteine suppressed mitochondrial membrane potential loss (upper), the release of cytochrome $\mathrm{c}$ and apoptosis-inducing factor to cytosol (lower). (F) Visualization of intracellular reactive oxygen species levels in fluorescence microscopy by staining with DCFA and mitochondria specific MitoSox Red. Chang cells treated with combination of $\mathrm{TiO}_{2}^{\mathrm{P} 25-70}$ and ultraviolet $\mathrm{A}$ irradiation show increased intracellular reactive oxygen species levels on both staining with DCFA and MitoSox Red.

Notes: $* P<0.005$. Error bars represent the mean \pm standard deviation of triplicate samples.

Abbreviations: AIF, UVA, ultraviolet A; DMSO, dimethylsulfoxide; AIF, apoptosis-inducing factor; HSP, heat shock protein; NAC, N-acetyl-L-cysteine.

Recently, some nanosized particles have been shown to have considerable biological activity and a cytotoxic effect in normal cells. However, the molecular basis for the cytotoxicity of these nanoparticles has yet to be defined. In this study, we investigated the molecular basis for nanosized $\mathrm{TiO}_{2}$-induced cell death in normal human cells.
Interestingly, as shown in Figure 3, treatment of $\mathrm{TiO}_{2}$ nanoparticles with ultraviolet A irradiation induced death of Chang cells in a hydrodynamic size-dependent manner. This observation provides us with some information on factors affecting the cytotoxicity of nanoparticles. According to Teeguarden et al, agglomeration and sedimentation of nanoparticles in cell culture media can cause a significant 
decrease in the nanoparticle dose delivered. ${ }^{14}$ Therefore, even when the same nanoparticle dose is administered, the dose of nanoparticles delivered (ie, the effective cellular dose delivered to adherent cells on the bottom) can vary significantly. Highly agglomerated and sedimented nanoparticles $\left(\mathrm{eg}, \mathrm{TiO}_{2}{ }^{\mathrm{P} 25-300}\right.$ ) will result in a higher dose delivered to adherent cells via gravitational settling and diffusion processes, while well dispersed nanoparticles (eg, $\mathrm{TiO}_{2}{ }^{\mathrm{P} 25-70}$ ) may result in a smaller dose being delivered to adherent cells because they are transported to adherent cells mostly via diffusion. Further, due to significant differences in their hydrodynamic size, the highly agglomerated nanoparticles sedimented on top of adherent cells may have cellular uptake and toxicity mechanisms which are completely different to those of well suspended nanoparticles. ${ }^{16,17}$ Therefore, the $20 \%$ cell death observed for $\mathrm{TiO}_{2}{ }^{\mathrm{P} 25-70}$ can be attributed solely to the cytotoxicity of $\mathrm{TiO}_{2}$ caused by diffusion-controlled delivery of sub-100 nm sized nanoparticles, while the other two cases (ie, $\mathrm{TiO}_{2}{ }^{\mathrm{P} 25-130}$ and $\mathrm{TiO}_{2}{ }^{\mathrm{P} 25-300}$ with cell death rates of $50 \%$ and $80 \%$, respectively) may have more complex delivery pathways as well as physicochemical processes, which may involve multiple cytotoxicity mechanisms.

We have shown that treatment with $\mathrm{TiO}_{2}{ }^{\mathrm{P} 25-70}$ under ultraviolet A irradiation induces apoptotic cell death through reactive oxygen species-mediated upregulation of the death receptor, Fas, and activation of the preapoptotic protein, Bax. Fas is a death receptor on the cell surface of a wide variety of cell types, and mediates rapid apoptosis. Although Fas is constitutively expressed in a variety of cell types, the role of Fas has also been evoked recently in apoptosis of various cell types in response to certain stimuli, ${ }^{32-34}$ ultraviolet irradiation, viral infection, and chemotherapeutic agents effectively increase Fas transcription and, in turn, upregulation of Fas is involved in apoptotic cell death. ${ }^{35} \mathrm{We}$ also provide further evidence that nanosized $\mathrm{TiO}_{2}{ }^{\mathrm{P} 25-70}$ together with ultraviolet A irradiation induces upregulation of Fas and subsequent caspase- 8 activation. Moreover, siRNA targeting of Fas attenuated $\mathrm{TiO}_{2}{ }^{\mathrm{P} 25-70}$-induced apoptotic cell death, suggesting that upregulation of Fas is involved in apoptotic cell death after treatment with $\mathrm{TiO}_{2}{ }^{\mathrm{P} 25-70}$. In response to stimuli such as etoposide, staurosporine, transforming growth factor- $\beta$, and ultraviolet irradiation, which require a mitochondria-dependent pathway for apoptosis, Bax is activated, translocated to the outer membrane of mitochondria, oligomerized therein, ${ }^{36,37}$ and, mitochondrial membranes are permeabilized, thereby releasing mitochondrial apoptogenic molecules into the cytosol. Similarly, we also found that $\mathrm{TiO}_{2}{ }^{\mathrm{P} 25-70}$ treatment under ultraviolet A irradiation redistributed Bax from the cytosol to the mitochondria. Moreover, siRNA targeting of Bax effectively attenuated mitochondrial membrane potential loss and apoptotic cell death caused by combined treatment with $\mathrm{TiO}_{2}{ }^{\mathrm{P} 25-70}$ and ultraviolet $\mathrm{A}$ irradiation. These results suggest that mitochondrial redistribution of Bax may trigger mitochondrial membrane potential loss and cause subsequent apoptotic cell death following treatment with $\mathrm{TiO}_{2}{ }^{\mathrm{P} 25-70}$. Accumulation of intracellular reactive oxygen species in response to diverse stimuli has been shown to lead the mitochondrial membrane permeability transition and subsequent activation of cell death machinery. ${ }^{9}$ Moreover, recent studies also provide evidence for the role of reactive oxygen species as potential inducers of mitochondrial dysfunction during apoptotic cell death in response to a variety of stimuli. ${ }^{38-40}$ Here, we provide further evidence that reactive oxygen species are essential for the mitochondrial membrane potential loss and subsequent cell death by $\mathrm{TiO}_{2}{ }^{\mathrm{P} 25-70}$ treatment. We show that an antioxidant, N-acetylL-cysteine, completely attenuates the Bax relocalization induced by $\mathrm{TiO}_{2}{ }^{\mathrm{P} 25-70}$ and mitochondrial cell death. Recently, several mechanisms have been proposed for reactive oxygen species-associated Bax activation. In nonstressed cells, apoptosis signal-regulating kinase 1 (ASK1) is known to be associated with reactive oxygen species-mediated apoptotic cell death. ${ }^{41,42}$ However, in our study, we failed to observe the involvement of ASK-1 in response to $\mathrm{TiO}_{2}{ }^{\mathrm{P} 25-70}$. Moreover, siRNA targeting of ASK-1 did not affect Bax activation and cell death (data not shown), indicating that reactive oxygen species-dependent Bax activation by $\mathrm{TiO}_{2}{ }^{\mathrm{P} 25-70}$ is independent of ASK-1 signaling. Therefore, the more precise mechanisms by which reactive oxygen species-dependent activation of Bax occurs in response to $\mathrm{TiO}_{2}{ }^{\mathrm{P} 25-70}$ remain to be elucidated. In summary, we have demonstrated in this study that $\mathrm{TiO}_{2}{ }^{\mathrm{P} 25-70}$ induces apoptotic cell death through reactive oxygen speciesdependent Fas upregulation and Bax activation in normal human liver cells. Elucidating the molecular mechanisms by which nanosized particles induce activation of cell death signaling pathways will be critical for the development of prevention strategies to minimize the cytotoxicity of nanomaterials.

\section{Acknowledgment}

This work was supported by the Korea Ministry of Environment and The Eco-Technopia 21 Project (091-091-081).

\section{Disclosure}

The authors report no conflicts of interest in this work. 


\section{References}

1. Shan Y, Ma S, Nie L, et al. Size-dependent endocytosis of single gold nanoparticles. Chem Commun (Camb). 2011;47(28):8091-8093.

2. Watari F, Takashi N, Yokoyama A, et al. Material nanosizing effect on living organisms: non-specific, biointeractive, physical size effects. J R Soc Interface. 2009;6 Suppl 3:S371-S388.

3. Li Y, Sun L, Jin M, et al. Size-dependent cytotoxicity of amorphous silica nanoparticles in human hepatoma HepG2 cells. Toxicol In Vitro. 2011;25(7):1343-1352.

4. Frohlich E, Kueznik T, Samberger C, Roblegg E, Wrighton C, PieberTR. Size-dependent effects of nanoparticles on the activity of cytochrome P450 isoenzymes. Toxicol Appl Pharmacol. 2010;242(3):326-332.

5. Nabeshi H, Yoshikawa T, Matsuyama K, et al. Size-dependent cytotoxic effects of amorphous silica nanoparticles on Langerhans cells. Pharmazie. 2010;65(3):199-201.

6. Itoh T, Terazawa R, Kojima K, et al. Cisplatin induces production of reactive oxygen species via NADPH oxidase activation in human prostate cancer cells. Free Radic Res. 2011;45(9):1033-1039.

7. Mizutani H. Mechanism of DNA damage and apoptosis induced by anticancer drugs through generation of reactive oxygen species. Yakugaku Zasshi. 2007;127(11):1837-1842. Japan.

8. Frye RE, Rossignol DA. Mitochondrial dysfunction can connect the diverse medical symptoms associated with autism spectrum disorders. Pediatr Res. 2011;69(5 Pt 2):41R-47R.

9. Fleury C, Mignotte B, Vayssiere JL. Mitochondrial reactive oxygen species in cell death signaling. Biochimie. 2002;84(2-3):131-141. French.

10. Chan WH, Wu CC, Yu JS. Curcumin inhibits UV irradiation-induced oxidative stress and apoptotic biochemical changes in human epidermoid carcinoma A431 cells. J Cell Biochem. 2003;90(2): $327-338$

11. Oberdorster G, Maynard A, Donaldson K, et al. Principles for characterizing the potential human health effects from exposure to nanomaterials: elements of a screening strategy. Part Fibre Toxicol. 2005;2:8.

12. Limbach LK, Li Y, Grass RN, et al. Oxide nanoparticle uptake in human lung fibroblasts: effects of particle size, agglomeration, and diffusion at low concentrations. Environ Sci Technol. 2005;39(23):9370-9376.

13. Oberdorster G, Oberdorster E, Oberdorster J. Concepts of nanoparticle dose metric and response metric. Environ Health Perspect. 2007; 115(6):A290.

14. Teeguarden JG, Hinderliter PM, Orr G, Thrall BD, Pounds JG. Particokinetics in vitro: dosimetry considerations for in vitro nanoparticle toxicity assessments. Toxicol Sci. 2007;95(2):300-312.

15. Sandhu KK, McIntosh CM, Simard JM, Smith SW, Rotello VM. Gold nanoparticle-mediated transfection of mammalian cells. Bioconjug Chem. 2002;13(1):3-6.

16. Chithrani BD, Ghazani AA, Chan WC. Determining the size and shape dependence of gold nanoparticle uptake into mammalian cells. Nano Lett. 2006;6(4):662-668.

17. Zhao F, Zhao Y, Liu Y, Chang X, Chen C. Cellular uptake, intracellular trafficking, and cytotoxicity of nanomaterials. Small. 2011;7(10): 1322-1337.

18. Cai R, Kubota Y, Shuin T, Sakai H, Hashimoto K, Fujishima A. Induction of cytotoxicity by photoexcited $\mathrm{TiO} 2$ particles. Cancer Res. 1992;52(8):2346-2348.

19. Kwon D, Lee SH, Kim J, Yoon TH. Dispersion, fractionation and characterization of sub-100 $\mathrm{nm} \mathrm{P} 25 \mathrm{TiO}_{2}$ nanoparticles in aqueous media. Toxicol Environ Health Sci. 2010;2(1):78-85.

20. Long TC, Saleh N, Tilton RD, Lowry GV, Veronesi B. Titanium dioxide (P25) produces reactive oxygen species in immortalized brain microglia (BV2): implications for nanoparticle neurotoxicity. Environ Sci Technol. 2006;40(14):4346-4352.

21. Kang SJ, Kim BM, Lee YJ, Chung HW. Titanium dioxide nanoparticles trigger p53-mediated damage response in peripheral blood lymphocytes. Environ Mol Mutagen. 2008;49(5):399-405.
22. Dhar S, Murawala P, Shiras A, Pokharkar V, Prasad BL. Gellan gum capped silver nanoparticle dispersions and hydrogels: cytotoxicity and in vitro diffusion studies. Nanoscale. 2012;4(2):563-567.

23. French RA, Jacobson AR, Kim B, Isley SL, Penn RL, Baveye PC. Influence of ionic strength, $\mathrm{pH}$, and cation valence on aggregation kinetics of titanium dioxide nanoparticles. Environ Sci Technol. 2009;43(5): 1354-1359.

24. Murdock RC, Braydich-Stolle L, Schrand AM, Schlager JJ, Hussain SM. Characterization of nanomaterial dispersion in solution prior to in vitro exposure using dynamic light scattering technique. Toxicol Sci. 2008; 101(2):239-253.

25. Wohlleben W, Schulze C, Kroll A, et al. Not ready to use - overcoming pitfalls when dispersing nanoparticles in physiological media. Nanotoxicology. 2008;2(2):51-61.

26. Zhang X, Yin L, Tang M, Pu Y. Optimized method for preparation of $\mathrm{TiO}_{2}$ nanoparticles dispersion for biological study. J Nanosci Nanotechnol. 2010;10(8):5213-5219.

27. Ji Z, Jin X, George S, et al. Dispersion and stability optimization of $\mathrm{TiO}_{2}$ nanoparticles in cell culture media. Environ Sci Technol. 2010;44(19): 7309-7314.

28. Gross A, McDonnell JM, Korsmeyer SJ. BCL-2 family members and the mitochondria in apoptosis. Genes Dev. 1999;13(15):1899-1911.

29. Gustafsson AB, Gottlieb RA. Bcl-2 family members and apoptosis, taken to heart. Am J Physiol Cell Physiol. 2007;292(1):C45-C51.

30. Ahamed M, Akhtar MJ, Siddiqui MA, et al. Oxidative stress mediated apoptosis induced by nickel ferrite nanoparticles in cultured A549 cells. Toxicology. 2011;283(2-3):101-108.

31. Liu S, Xu L, Zhang T, Ren G, Yang Z. Oxidative stress and apoptosis induced by nanosized titanium dioxide in PC12 cells. Toxicology. 2010; 267(1-3):172-177.

32. Bogatkevich GS, Gustilo E, Oates JC, et al. Distinct PKC isoforms mediate cell survival and DNA synthesis in thrombin-induced myofibroblasts. Am J Physiol Lung Cell Mol Physiol. 2005;288(1):L190-L201.

33. Geng L, Zhu B, Dai BH, et al. A let-7/Fas double-negative feedback loop regulates human colon carcinoma cells sensitivity to Fas-related apoptosis. Biochem Biophys Res Commun. 2011;408(3):494-499.

34. Jelaska A, Korn JH. Role of apoptosis and transforming growth factor beta1 in fibroblast selection and activation in systemic sclerosis. Arthritis Rheum. 2000;43(10):2230-2239.

35. Matsuda N, Yamamoto S, Takano K, et al. Silencing of fas-associated death domain protects mice from septic lung inflammation and apoptosis. Am J Respir Crit Care Med. 2009;179(9):806-815.

36. Desagher S, Osen-Sand A, Nichols A, et al. Bid-induced conformational change of Bax is responsible for mitochondrial cytochrome c release during apoptosis. J Cell Biol. 1999;144(5):891-901.

37. Eskes R, Desagher S, Antonsson B, Martinou JC. Bid induces the oligomerization and insertion of Bax into the outer mitochondrial membrane. Mol Cell Biol. 2000;20(3):929-935.

38. Choi EM, Lee YS. Mitochondrial defects and cytotoxicity by antimycin A on cultured osteoblastic MC3T3-E1 cells. Food Chem Toxicol. 2011;49(9):2459-2463.

39. Piao MJ, Kang KA, Lee IK, et al. Silver nanoparticles induce oxidative cell damage in human liver cells through inhibition of reduced glutathione and induction of mitochondria-involved apoptosis. Toxicol Lett. 2011;201(1):92-100.

40. Wu PP, Liu KC, Huang WW, et al. Triptolide induces apoptosis in human adrenal cancer NCI-H295 cells through a mitochondrialdependent pathway. Oncol Rep. 2011;25(2):551-557.

41. Pan J, Chang Q, Wang X, et al. Reactive oxygen species-activated Akt/ ASK1/p38 signaling pathway in nickel compound-induced apoptosis in BEAS 2B cells. Chem Res Toxicol. 2010;23(3):568-577.

42. Yang WH, Fong YC, Lee CY, et al. Epigallocatechin-3-gallate induces cell apoptosis of human chondrosarcoma cells through apoptosis signal-regulating kinase 1 pathway. J Cell Biochem. 2011;112(6): 1601-1611. 


\section{Supplementary figures}

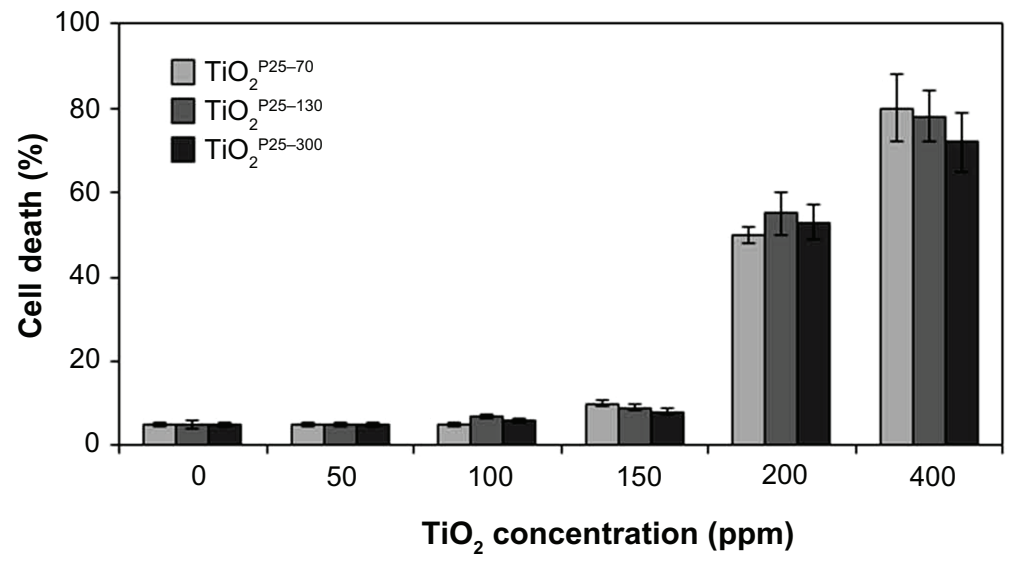

Figure SI Measurement of cell death by FACS analysis after propidium iodide staining. Chang cells were treated with $\mathrm{TiO}_{2}$ nanoparticles of different hydrodynamic size distributions $\left(\mathrm{TiO}_{2}{ }^{\mathrm{P} 25-70}, \mathrm{TiO}_{2}{ }^{\mathrm{P} 25-130}\right.$ and $\left.\mathrm{TiO}_{2}{ }^{\mathrm{P} 25-300}\right)$ at each concentration $(0,50,100,150200,400 \mathrm{ppm})$ for 24 hours, and cell death was measured by flow cytometry with propidium iodide staining. Treatment with a lower concentration of $\mathrm{TiO}_{2}$ nanoparticles than $200 \mathrm{ppm}$ did not cause significant cell death, while treatment with a higher concentration (200 and $400 \mathrm{ppm}$ ) resulted in dramatic cell death at any $\mathrm{TiO}_{2}$ nanoparticle size.

Note: Error bars represent the mean \pm standard deviation of triplicate samples.

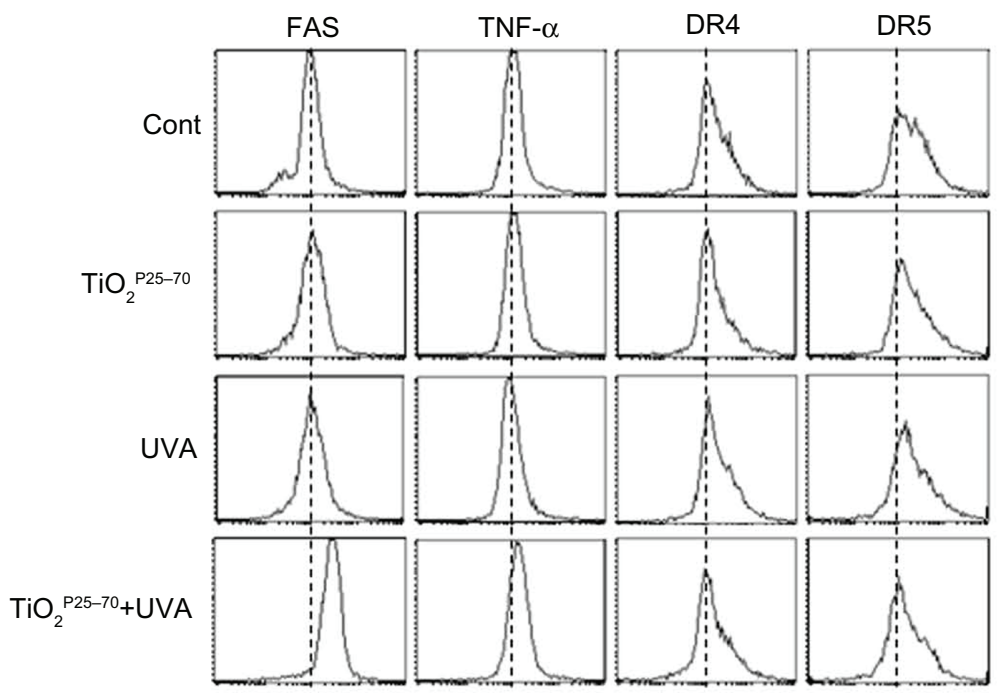

Figure S2 Representative FACS plots for measurement of cell death receptor expression levels. FACS analysis reveals upregulation of Fas expression in Chang cells treated with $\mathrm{TiO}_{2}{ }^{\mathrm{P} 25-70}$ in combination with ultraviolet $\mathrm{A}$ irradiation, while single treatment with either $\mathrm{TiO}_{2}{ }^{\mathrm{P} 25-70}$ or ultraviolet $\mathrm{A}$ did not upregulate the level of Fas expression. Expression levels of other death receptors, ie, TNF, DR4, and DR5, were not altered in Chang cells by combined treatment with TiO ${ }_{2}^{\mathrm{P} 25-70}$ and ultraviolet $\mathrm{A}$ irradiation. Abbreviations: TNF, tumor necrosis factor; DR, death receptor; UVA, ultraviolet A.

\section{Publish your work in this journal}

The International Journal of Nanomedicine is an international, peerreviewed journal focusing on the application of nanotechnology in diagnostics, therapeutics, and drug delivery systems throughout the biomedical field. This journal is indexed on PubMed Central, MedLine, CAS, SciSearch $\AA$, Current Contents $\AA /$ Clinical Medicine,
Journal Citation Reports/Science Edition, EMBase, Scopus and the Elsevier Bibliographic databases. The manuscript management system is completely online and includes a very quick and fair peer-review system, which is all easy to use. Visit http://www.dovepress.com/ testimonials.php to read real quotes from published authors. 